\title{
Simulation of a 100-MW solar-powered thermo-chemical air separation system combined with an oxy-fuel power plant for bio-energy with carbon capture and storage (BECCS)
}

\author{
Clemens F. Patzschke ${ }^{1} \cdot$ Husain Bahzad $^{1}$ • Matthew E. Boot-Handford ${ }^{1}$ • \\ Paul S. Fennell ${ }^{1}$
}

Received: 5 December 2018 / Accepted: 27 June 2019 / Published online: 10 August 2019

(C) The Author(s) 2019

\begin{abstract}
The combination of concentrated solar power-chemical looping air separation (CSP-CLAS) with an oxy-fuel combustion process for carbon dioxide $\left(\mathrm{CO}_{2}\right)$ capture is a novel system to generate electricity from solar power and biomass while being able to store solar power efficiently. In this study, the computer program Advanced System for Process Engineering Plus (ASPEN Plus) was used to develop models to assess the process performance of such a process with manganese $(\mathrm{Mn})$-based oxygen carriers on alumina $\left(\mathrm{Al}_{2} \mathrm{O}_{3}\right)$ support for a location in the region of Seville in Spain, using real solar beam irradiance and electricity demand data. It was shown that the utilisation of olive tree prunings (Olea europaea) as the fuel-an agricultural residue produced locally_results in negative $\mathrm{CO}_{2}$ emissions (a net removal of $\mathrm{CO}_{2}$ from the atmosphere). Furthermore, it was found that the process with an annual average electricity output of $18 \mathrm{MW}$ would utilise $2.43 \%$ of Andalusia's olive tree prunings, thereby capturing $260.5 \mathrm{k}$-tonnes of $\mathrm{CO}_{2}$, annually. Drawbacks of the system are its relatively high complexity, a significant energy penalty in the CLAS process associated with the steam requirements for the loop-seal fluidisation, and the gas storage requirements. Nevertheless, the utilisation of agricultural residues is highly promising, and given the large quantities produced globally ( $\sim 4$ billion tonnes/year), it is suggested that other novel processes tailored to these fuels should be investigated, under consideration of a future price on $\mathrm{CO}_{2}$ emissions, integration potential with a likely electricity grid system, and based on the local conditions and real data.
\end{abstract}

Paul S. Fennell

p.fennell@imperial.ac.uk

1 Department of Chemical Engineering, Imperial College London, South Kensington Campus, London SW7 2AZ, UK 
Keywords Chemical looping air separation (CLAS) · Mn oxygen carrier · BECCS · Energy storage Concentrated solar power (CSP) Negative $\mathrm{CO}_{2}$ emissions · Climate change mitigation . Chemical looping $\cdot \mathrm{CLOU} \cdot$ Oxygen uncoupling $\cdot$ Bio energy with $\mathrm{CO}_{2}$ capture $\cdot \mathrm{CO}_{2}$ capture . Olive tree pruning $\cdot$ Olive grove

\section{Introduction}

The primary driver of climate change is anthropogenic emissions of carbon dioxide $\left(\mathrm{CO}_{2}\right)$ (IPCC 2005). A high share of this is coming from the burning of fossil fuels for transport, energy production and industrial processes (IPCC 2005). Oxy-fuel combustion is a novel combustion process, which is based on the substitution of air with oxygen $\left(\mathrm{O}_{2}\right)$-enriched recycled flue gas during combustion. This results in the production of a $\mathrm{CO}_{2}$-rich stream. After removal of steam $\left(\mathrm{H}_{2} \mathrm{O}\right)$ and impurities, the $\mathrm{CO}_{2}$ stream can be compressed and permanently sequestered in geological formations. The production of $\mathrm{O}_{2}$ is conventionally done via cryogenic distillation, which results in a relatively high energy penalty $\left(\sim 0.4 \mathrm{kWh} / \mathrm{m}^{3}{ }_{\mathrm{n}}\right)$ for air separation (Zhou et al. 2015). Recently, chemical looping air separation (CLAS) has been proposed for air separation (Moghtaderi 2010). To achieve the same combustion characteristics, a higher $\mathrm{O}_{2}$ volume fraction (here assumed to be $27 \mathrm{vol} \%$ ) is required during oxy-fuel combustion than during combustion in air (Riaza et al. 2012). Tagliaferry et al. (Tagliaferri et al. 2018) carried out a life cycle assessment of various systems for electricity production and reported that the CLAS + oxy-fuel process had the lowest (and only negative) global warming potential in comparison with the other studied conventional and novel fossil fuel and renewable electricity generation technologies. In this study, the enthalpy required for the $\mathrm{O}_{2}$ uncoupling is provided by concentrated solar power, and storage of $\mathrm{O}_{2}+\mathrm{CO}_{2}$ and $\mathrm{CO}_{2}$ enables operation of the CLAS process and the oxy-fuel process at different times of the day. The process is illustrated in Fig. 1(a). This bio-energy with carbon capture and storage (BECCS) process can result in a net transfer of carbon from the atmosphere to the geosphere (negative $\mathrm{CO}_{2}$ emissions), as illustrated in Fig. 1(b).

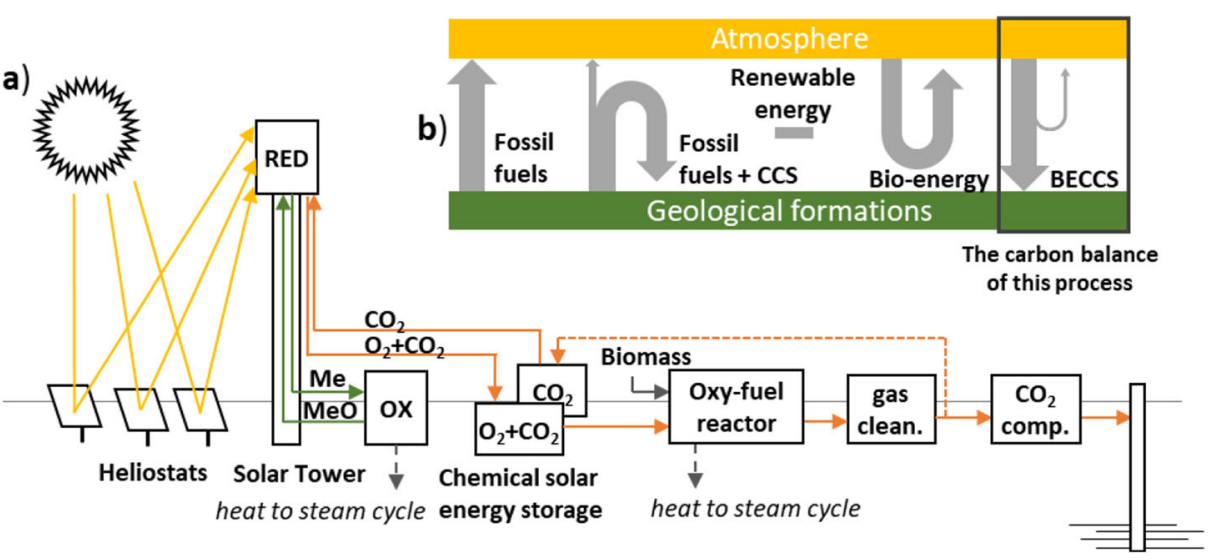

Fig. 1 (a) Schematic diagram of the solar-powered CLAS process combined with an oxy-fuel process for BECCS and (b) carbon balances of power generation processes with a highlighted balance for BECCS adapted from Karlsson and Byström (2011) 
The simulated plant is assumed to be located in the region of Seville in Spain, where other prototypes of concentrated solar power (CSP) plants are currently tested (NREL 2018), and for which detailed sun irradiance data is available (Blair et al. 2018). Seville is located in Andalusia. The criterion for the selection of biomass for combustion in the BECCS plant was that it had to be produced in Andalusia to minimise emissions for transportation of the fuel. Figure 2, below, illustrates the cumulated energy contained in different types of biomass produced in Andalusia.

The biomass type with the largest energy potential in Fig. 2 is olive grove - the pruning of olive trees. It is an agricultural residue that is currently either illegally burned or left on the ground to decay (García-Maraver et al. 2012). In both cases, the contained carbon is released as $\mathrm{CO}_{2}$ into the atmosphere. In Andalusia, about four million tons of olive tree pruning are produced annually. Owing to the availability and quantity of this type of biomass, olive tree prunings were selected as the fuel for the BECCS plant in this study.

Next, the oxygen storage material was selected. Only some transition metal oxides systems, such as those containing cobalt (Co) ( $\mathrm{Li}$ et al. 2008; Moghtaderi 2010; Shah et al. 2012), copper $(\mathrm{Cu})$ (Moghtaderi 2010; Shah et al. 2012; Song et al. 2014) or manganese (Mn) (Moghtaderi 2010, Shah et al. 2012) are capable of releasing gaseous $\mathrm{O}_{2}$ in $\mathrm{CO}_{2}$ at conditions that are relevant for the CLAS process. Co-based oxygen carriers are toxic and irreversibly react with oxides of sulphur (S) in the recycled flue gases to produce $\mathrm{CoSO}_{4}$ within the temperature range of a CLAS process $\left(800-900{ }^{\circ} \mathrm{C}\right)$. As a consequence, Co-based oxygen carriers were removed from consideration (Shah et al. 2013).

The system $\mathrm{CuO} / \mathrm{Cu}_{2} \mathrm{O}$, which reacts according to

$$
4 \mathrm{CuO}+\mathrm{n} \mathrm{CO}_{2} \leftrightarrow 2 \mathrm{Cu}_{2} \mathrm{O}+\mathrm{O}_{2}+\mathrm{n} \mathrm{CO}_{2}, \Delta H_{r, 800}=264.7 \mathrm{~kJ} \mathrm{~mol}^{-1}
$$

has the highest theoretical oxygen carrying capacity (mass of $\mathrm{O}_{2}$ available for uncoupling/mass of fully oxidised oxygen carrier) of the three transition metals with $\mathrm{O}_{2}$ release functionality of $10.1 \mathrm{wt} \%$. However, the phase equilibrium temperature within an atmosphere of $27 \mathrm{vol} \% \mathrm{O}_{2}$ is $1026{ }^{\circ} \mathrm{C}$, which means that even higher temperatures are needed to release $\mathrm{O}_{2}$ with sufficiently high rates. These temperatures are approaching

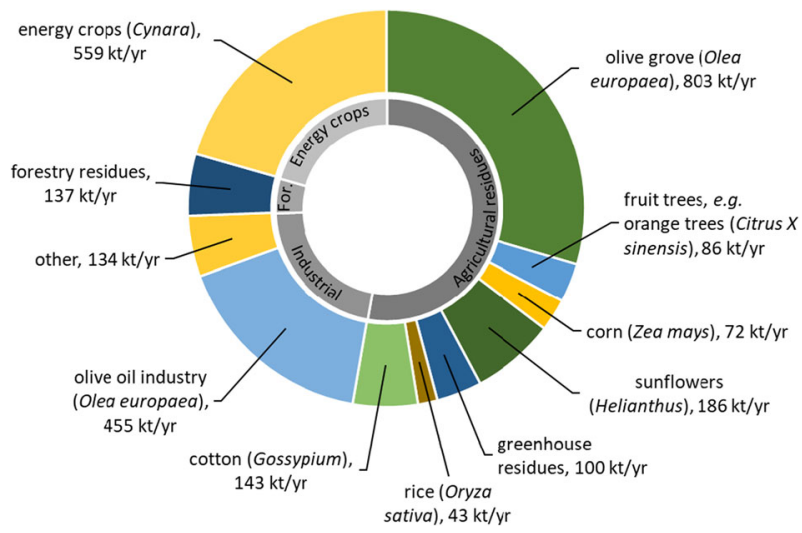

Fig. 2 Biomass potential in Andalusia in kilotonne oil equivalent (ktoe) per annum, excluding municipal sewage sludge, mud and animal waste. The data is taken from García-Maraver et al. (2012) 
upper metallurgical limits for $\mathrm{Cu}$-based oxygen carriers and beyond those possible with current state-of-the-art CSP technology. A further disadvantage of the copper oxides is their inferior mechanical properties, making them prone to agglomeration and attrition (Cho et al. 2004).

$\mathrm{Mn}_{2} \mathrm{O}_{3} / \mathrm{Mn}_{3} \mathrm{O}_{4}$ reacts according to

$$
6 \mathrm{Mn}_{2} \mathrm{O}_{3}+\mathrm{n} \mathrm{CO} \leftrightarrow 4 \mathrm{Mn}_{3} \mathrm{O}_{4}+\mathrm{O}_{2}+\mathrm{n} \mathrm{CO}_{2} \Delta H_{r, 800}=144.2 \mathrm{~kJ} \mathrm{~mol}^{-1}
$$

The $\mathrm{O}_{2}$ release capacity of $\mathrm{Mn}_{2} \mathrm{O}_{3} / \mathrm{Mn}_{3} \mathrm{O}_{4}\left(3.4 \mathrm{wt} \%\right.$ ) is lower than that of $\mathrm{CuO} / \mathrm{Cu}_{2} \mathrm{O}$, but the position of the phase equilibrium temperature in $27 \mathrm{vol} \% \mathrm{O}_{2}$ is lower at $916{ }^{\circ} \mathrm{C}$. To have sufficiently high kinetics, the reducer would operate at a temperature of around $950{ }^{\circ} \mathrm{C}$, which is within the range at which current CSP systems can provide heat. As such, Mn-based materials are the only feasible single-metal oxide oxygen storage materials suitable for CSPCLAS with current state-of-the-art CSP technology and reactor vessel materials. The combination of a CSP-CLAS system with the combustion of biomass in oxy-fuel mode is the subject of this study. This combined process would allow to achieve negative $\mathrm{CO}_{2}$ emissions as well as to storage solar energy in the form of $\mathrm{O}_{2}$-enriched $\mathrm{CO}_{2}$ for the operation of the BECCS plant at during the night-time.

\section{Description and modelling of the process}

The process consists of four subsystems: (i) the CSP-CLAS system, (ii) an $\mathrm{O}_{2}+\mathrm{CO}_{2}$ storage system, (iii) the oxy-fuel combustion system and (iv) the steam cycle. The flow sheet of the model developed in the chemical engineering modelling program, ASPEN Plus, of this process is shown in Fig. 3, below.

The considerations leading to the design of this process are described in detail in the sections below.

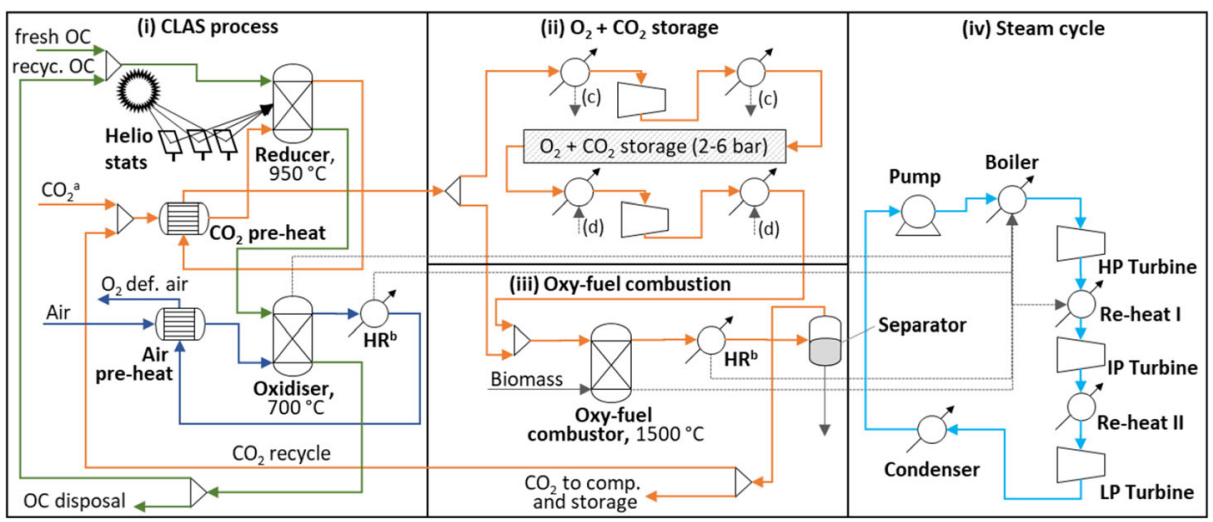

Fig. 3 Flow sheet of the process of this study. The streams are coloured to indicate flows of oxygen carriers (green), $\mathrm{CO}_{2}$ and $\mathrm{O}_{2}+\mathrm{CO}_{2}$ (orange), air and $\mathrm{O}_{2}$-deficient air (dark blue) and steam (light blue). (a) $\mathrm{CO}_{2}$ stream from gas storage during operation of the CLAS process when the BECCS plant is not producing sufficient $\mathrm{CO}_{2}$. (b) $\mathrm{HR}$ abbreviates 'heat recovery'. (c) Heat stream from $\mathrm{O}_{2}+\mathrm{CO}_{2}$ compression is used to preheat air. (d) Heat stream into $\mathrm{O}_{2}+\mathrm{CO}_{2}$ expansion is provided from oxy-fuel heat recovery 


\subsection{Concentrated solar power}

The heat required for the endothermic reaction of the $\mathrm{O}_{2}$ uncoupling is provided by concentrated solar power. A suitable design for the collectors is a heliostat field, which consists of an array of planar mirrors (Barlev et al. 2011). The mirrors are reflecting the incident sunlight focused on the receiver, which is located on the top of a tower in the centre of the array (Barlev et al. 2011). The solar power heat flow, $\dot{Q}_{\mathrm{CSP}}$, was calculated by

$$
\underset{\mathrm{CSP}}{Q}=R_{\mathrm{BI}} \cdot A_{\mathrm{HS}} \cdot \eta_{\mathrm{HS}+\mathrm{R}}
$$

where $R_{\mathrm{BI}}$ is the area specific solar beam irradiance, $A_{\mathrm{HS}}$ the area of the panels of the heliostats and $\eta_{\mathrm{HS}+\mathrm{R}}$ the combined efficiency of the heliostats and the receiver. For $\eta_{\mathrm{HS}+\mathrm{R}}$, a value of 0.49 was assumed (Zhang et al. 2013). The data for the beam irradiance for Seville in Spain was taken from the System Advisor Model (SAM) (Blair et al. 2018) - a performance calculator and database developed by the US D.o.E.'s National Renewable Energy Laboratory (NREL). The hourly beam irradiance data averaged for selected months is shown in Fig. 4, below.

\subsection{The chemical looping air separation system}

In this study, the reducer is defined as the reactor in which the oxygen carrier releases gaseous $\mathrm{O}_{2}$, while the oxidation states of the oxygen carriers' active material are reduced. The reactor is assumed to operate at atmospheric pressure and was modelled in ASPEN Plus as a RGIBBS reactor - an equilibrium reactor. The operating temperature of the reactor was set to $916{ }^{\circ} \mathrm{C}$ to obtain an $\mathrm{O}_{2}$ outlet concentration of $27 \mathrm{vol} \%$. The oxidiser also operates at atmospheric pressure and was modelled as an RGIBBS reactor, too. In reality, both reactors would likely be fluidised bed reactors with a solid-recycle. The outlet concentration of the oxidiser was assumed to be $8 \mathrm{vol} \%$, which corresponds to an operating temperature of the RGIBBS reactor of $700{ }^{\circ} \mathrm{C}$. Significantly lower $\mathrm{O}_{2}$ volume fractions at the outlet would result in slow reaction

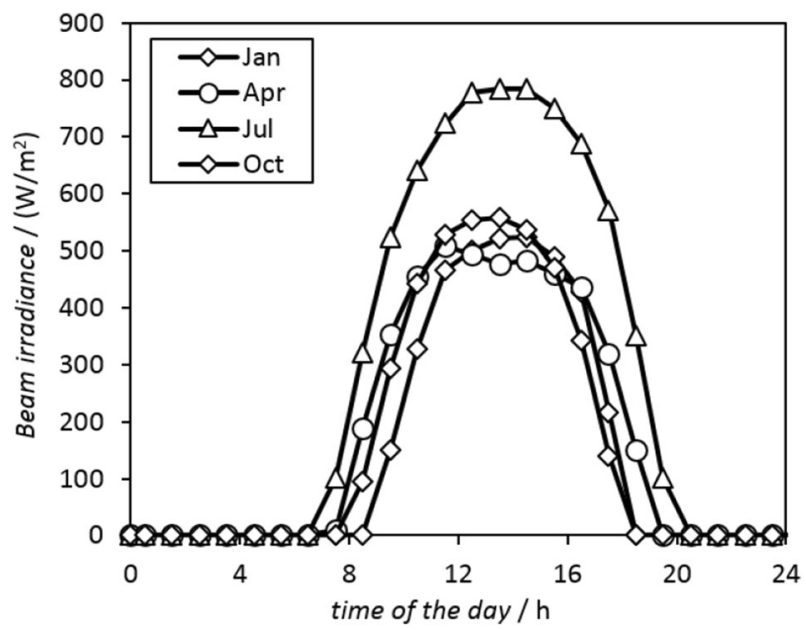

Fig. 4 Solar beam irradiance data from the SAM tool for the region Seville, Spain. The hourly solar energy input into the CLAS system of this study was calculated using the solar beam irradiance data and Eq. (3) 
Table 1 Proximate analysis, calorific value and ultimate analysis of olive tree pruning, which is used as the fuel in this study (Vamvuka et al. 2014)

\begin{tabular}{lcclr}
\hline Proximate analysis (wt \%) & Wet & Dry & Ultimate analysis (wt\%) & Dry \\
Fixed carbon & 19.0 & 21.3 & Carbon & 48.5 \\
Volatile matter & 69.4 & 77.9 & Hydrogen & 5.3 \\
Ash & 0.7 & 0.8 & Oxygen & 44.7 \\
Moisture & $11.0^{\mathrm{a}}$ & 0.0 & Nitrogen & 0.7 \\
& & & Sulphur & 0.0 \\
Higher heating value (HHV) & & & Ash & 0.8 \\
HHV on dry basis: & & $19.1 \mathrm{MJ} / \mathrm{kg}$ & Moisture & 0.0 \\
\hline
\end{tabular}

The moisture content of 'wet' olive tree pruning was taken from García-Maraver et al. (2012)

rates, resulting in a larger and more capital intense oxidiser (Lyngfelt et al. 2001). A constant temperature in the oxidiser is maintained by transferring excess heat to the steam cycle. A further heat recovery unit downstream of the oxidiser utilises some of the enthalpy contained in the exhaust gas stream, thereby cooling it down to $600{ }^{\circ} \mathrm{C}$. This recovered heat is also transferred to the steam cycle. The exhaust gas leaving this heat recovery unit and the gas stream leaving the reducer are used to preheat the cold air stream (to about $600{ }^{\circ} \mathrm{C}$ ) and the cold $\mathrm{O}_{2}+\mathrm{CO}_{2}$ stream (to about $900{ }^{\circ} \mathrm{C}$ ), respectively. Loop-seals - a pneumatical sealing assembly that allows the oxygen carriers entering the reactor while preventing gas leakage from the reactor - are used at the oxygen carrier inlet of the oxidiser and the reducer. These seals are assumed to be fluidised with process steam. Marx et al. (2013) reported for pilot plant test in a $10 \mathrm{MW}_{\text {th }}$ unit steam requirements for the fluidisation of the loop-seal to the fuel reactor and to the air reactor of $178.2 \mathrm{~kg} \mathrm{~h}^{-1}$ and $169.9 \mathrm{~kg} \mathrm{~h}^{-1}$, respectively. It was assumed that through careful design of the loop-seals, the steam requirements in an industrial-scale process can be reduced by $50 \%$ (Zerobin et al. 2016), which corresponds to a steam-to-oxygen carrier mass ratio of about 0.0257 for both loop-seals. To estimate the steam requirements for the CLAS process of this study, the value was linearly extrapolated to match the oxygen carrier circulation rate.

\subsection{Oxy-fuel combustion of biomass}

Olive tree prunings are taken as the solid fuel for the oxy-fuel combustion. The simulation of the solid fuel was carried out using the non-conventional solids package in ASPEN Plus, with the solid fuel specifications as summarised in Table 1, below.

The biomass drying and biomass combustion were modelled according to the ASPEN Plus's standard procedure for the combustion of non-conventional solids (AspenTech 2013). This involved a RSTOIC reactor (a stoichiometric reactor in which the extent or conversion of the reaction is specified) for the biomass drying, in which the moisture content was reduced

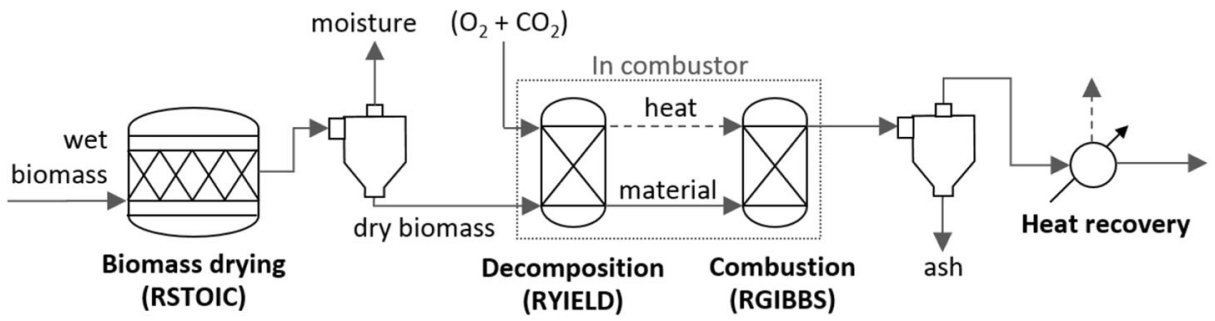

Fig. 5 The reactor configuration in ASPEN Plus for the simulation of the drying and combustion of biomass 
from $11.0 \mathrm{wt} \%$ to zero, as well as a RYIELD reactor (a reactor for which the yield of products is specified) and a RGIBBS reactor for the decomposition and the combustion, respectively. Those were followed by a separator (SSPLIT), to separate the ash and the combustion products. The heat of the combustion products was transferred to the steam cycle. The process is illustrated in Fig. 5, below.

In a typical simulation, the composition of the flue gas leaving the oxy-fuel combustor was $\mathrm{CO}_{2}=80.5$ vol $\%, \mathrm{H}_{2} \mathrm{O}=15.1$ vol $\%, \mathrm{O}_{2}=0.9$ vol $\%, \mathrm{~N}_{2}=0.2$ vol $\%, \mathrm{H}_{2}=0.1$ vol $\%$.

\subsection{Steam cycle, electricity generation and heat integration}

The heat generated in the oxy-fuel combustor is utilised to raise steam to run a low-pressure (LP), an intermediate-pressure (IP), and a high-pressure (HP) steam turbine (ST), via a heat recovery steam generator (HRSG). The operating conditions of the parts of the steam cycle are summarised in Table 2, below.

The fuel used in this study is olive tree prunings, and the higher heating value (HHV) is assumed to be $19.1 \mathrm{MJ} / \mathrm{kg}$ (c.f. Table 1), as reported in Vamvuka et al. (2014). The net plant efficiency of the combined process, $\eta_{\text {plant }}$, is calculated by the equation proposed by Porrazzo et al. (2016):

$$
\eta_{\text {plant }}=\frac{W_{\text {total }}}{\underset{\text { biomass }}{\dot{Q}}+\underset{\text { solar }}{\dot{Q}}=\frac{W_{\text {turbines }}-W_{\text {compressors }}-W_{\text {pumps }}}{m_{\text {biomass }} \cdot H H V+A_{H S} \cdot R_{I B}}}
$$

where $\dot{Q}_{\text {biomass }}$ is the heat released during the combustion of biomass, which is equal to the product of its mass flow rate, $\dot{m}_{\text {biomass }}$, and its heating value, $H H V \cdot \dot{Q}_{\text {solar }}$ is the heat of incoming solar radiation, which in turn was calculated by Eq. (3). Therefore, $\eta_{\text {plant }}$ refers to the total energy added to the system, which is the sum of the energy added by the two different types of primary energy carriers, viz. solar power and biomass.

$W_{\text {total }}$, is the total work available to run the electrical generators and $W_{\text {turbines }}, W_{\text {compressors }}$, and $W_{\text {pumps }}$ are the work of the turbines, compressors and pumps, respectively. The electrical power output was estimated by

$$
P_{\text {elec. }} \approx \frac{W_{\text {turbines }}-W_{\text {compressors }}-W_{\text {pumps }}}{t}
$$

where $P_{\text {elec. }}$ is the electrical power output and $t$ is time. The objective function was for $P_{\text {elec. }}$ to be proportional to the hourly electricity demand of Spain at any given hour. The demand data

Table 2 Operational parameter for the steady-state operation of the CSP-CLAS+oxy-fuel system

\begin{tabular}{llll}
\hline Stream & Inlet temperature $\left({ }^{\circ} \mathrm{C}\right)$ & Outlet temperature $\left({ }^{\circ} \mathrm{C}\right)$ & Pressure (bar) \\
\hline HP steam from HRSG & 30 & 613 & 260 \\
HP steam to HP ST & 613 & 515 & 150 \\
IP steam to IP reheat & 515 & 613 & 150 \\
IP steam to IP ST & 613 & 480 & 150 \\
LP steam to LP reheat & 480 & 613 & 70 \\
LP steam to LP ST & 613 & 33 & 70 \\
Cooling water to condenser & 30 & 30 & 0.043 \\
Condensate return to HRSG & 30 & 613 & 260 \\
\hline
\end{tabular}


averaged for every calendar month of the year 2015 was taken from The European Network of Transmission System Operators for Electricity (ENTSOE) and is shown in Fig. 6, below (ENTSOE 2018).

\subsection{Sizing of the CSP-CLAS and the oxy-fuel system}

The CSP-CLAS and the oxy-fuel systems depend on each other, since the CSP-CLAS system produces the $\mathrm{O}_{2}+\mathrm{CO}_{2}$, which is consumed by the oxy-fuel system. Since the CLAS system operates predominantly during the day and the oxy-fuel system predominantly during the night, significant quantities of $\mathrm{O}_{2}+\mathrm{CO}_{2}$ and $\mathrm{CO}_{2}$ need to be stored. The two boundary conditions to size the two systems were the following: (i) the input of thermal energy into the reducer of the CLAS system has to be equal to the hourly varying solar power calculated by Eq. (3) using the solar beam irradiance data for the region Seville, Spain, and (ii) the electricity output has to vary proportionally to Spain's hourly electricity demand (data from ENTSOE (2018) for the year 2015 was used). Before this dynamic simulation was conducted, a steady-state model with a 100-MW solar power input (at the receiver) was developed. In this steady-state simulation, the $\mathrm{O}_{2}+\mathrm{CO}_{2}$ mixture produced in the CSP-CLAS system was directly used for the oxy-fuel combustion of the olive tree prunings (without intermediate gas storage). For the dynamic simulation, the flow rates of oxygen carrier and gaseous fuel as well as the split ratios that determined the amounts of 'gas stored' and 'gas directly utilised' were adjusted to produce variants of the system, with sun power input and electricity power output at any given hour of the day corresponding to the solar power input and electricity demand, respectively. Then, a third boundary condition was introduced, specifying that at the end of the day, the amount of $\mathrm{O}_{2}+\mathrm{CO}_{2}$ stored has to equal the amount of gas stored at the beginning of the day. This boundary condition was applied by calculating the change of stored $\mathrm{O}_{2}+\mathrm{CO}_{2}$ over 24 h. A negative balance, which means more $\mathrm{O}_{2}+\mathrm{CO}_{2}$ was consumed over the course of the

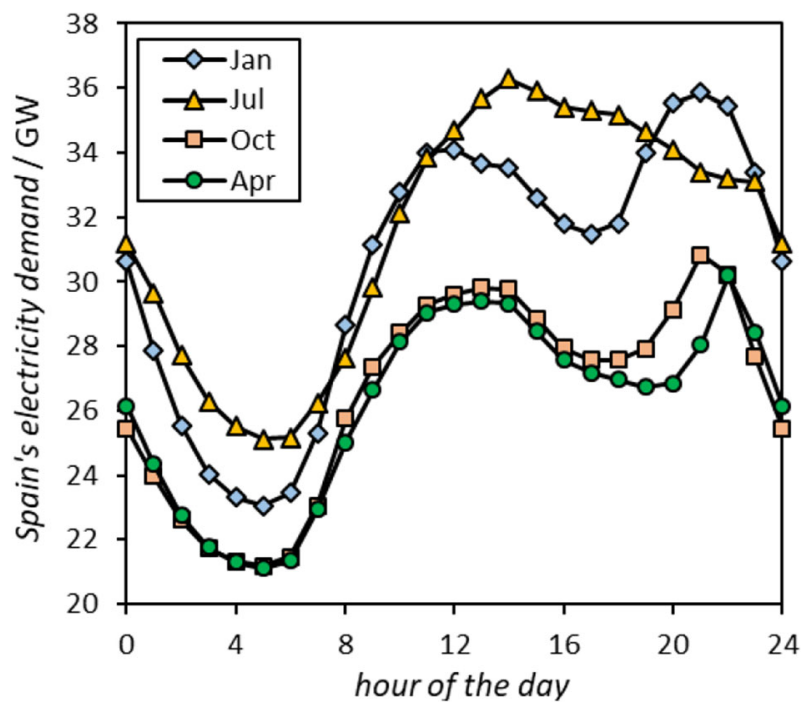

Fig. 6 Spain's hourly electricity demand averaged for selected months. The objective function of the optimisation of this study was to produce electricity proportional to this energy demand. The data is taken from the European Network of Transmission System Operators for Electricity (ENTSOE 2018) 
day than produced, implied that the BECCS plant combusts too much biomass and thus, the mass flow rate of biomass was reduced. A positive balance, in turn, meant that not all of the available $\mathrm{O}_{2}+\mathrm{CO}_{2}$ was utilised, and the $\mathrm{O}_{2}+\mathrm{CO}_{2}$ and biomass flow rate was thus increased. After adjusting the size of the BECCS plant, the performance of the plant was calculated for every hour of the day. This iteration was repeated until the amount of $\mathrm{O}_{2}+\mathrm{CO}_{2}$ stored at the beginning of the day and the end of the day was the same. This iteration procedure was then repeated for the different cases (c.f. Fig. 6) as well as for the different months (c.f. Fig. 8). For the latter, solar radiation and electricity demand data for January, April, July and October were used.

\section{Results and discussion}

\subsection{Synergetic operation of both processes in steady-state}

The results of the steady-state simulation are reported in Table 3, below.

Using Eq. (4), a net plant efficiency during steady-state of $26.3 \%$ was calculated. However, care has to be taken when comparing this value with calculated efficiencies of other thermal power plants, since here two types of energy carriers are used (solar power and biomass). When only operating the BECCS plant and the CSP-CLAS plant with the steam cycle, the steady-state net plant efficiency is $37.0 \%$ and $17.8 \%$, respectively.

\subsection{Synergetic operation of both processes in dynamic mode}

In dynamic operation and with a minimum load factor of the BECCS plant equal to zero, the two systems operate mostly separately - the BECCS system predominantly at night and the CSP-CLAS system during the hours of sunshine. Only a few hours of simultaneous operations occur during the mornings and evenings. This restricts the heat integration between the BECCS system and CSP-CLAS system. A further drawback of the independent operation is the energy penalty associated with gas storage. Firstly, the $\mathrm{O}_{2}$-enriched $\mathrm{CO}_{2}$ is sent to storage at $80{ }^{\circ} \mathrm{C}$, while is withdrawn from the storage at $20{ }^{\circ} \mathrm{C}$. The energy of the difference in temperatures is assumed to be dissipated into the ground and hence lost from the system. Secondly, adiabatic and mechanical isentropic inefficiencies during compression of the $\mathrm{O}_{2}+$ $\mathrm{CO}_{2}$ to 2-6 bar and expansion back to atmospheric pressure result in further losses of energy.

Table 3 Parameter and results of the steady-state simulation of the CSP-CLAS + oxy-fuel process

\begin{tabular}{lllr}
\hline $\begin{array}{l}\text { Parameters of the reducer } \\
\text { Solar power to reducer }\end{array}$ & $100 \mathrm{MW}$ & Parameters of oxy-fuel combustion \\
$\begin{array}{l}\text { Mass flow rate of } \mathrm{CO}_{2} \text { (inlet) } \\
\text { Operating temperature }\end{array}$ & $113,845 \mathrm{~kg} / \mathrm{h}$ & & $24,907 \mathrm{~kg} / \mathrm{h}$ \\
$\mathrm{O}_{2}$ concentration at outlet & $916^{\circ} \mathrm{C}$ & Parameters of the steam cycle & $58,392 \mathrm{~kg} / \mathrm{h}$ \\
Flow rate of the $\mathrm{O}_{2}+\mathrm{CO}_{2}$ & $27 \mathrm{vol} \%$ & $\mathrm{H}_{2} \mathrm{O}$ mass flow rate & $20.9 \mathrm{MW}$ \\
Loop-seals fluidisation steam req. & $144,460 \mathrm{~kg} / \mathrm{h}$ & Power generated in LPT & $3.7 \mathrm{MW}$ \\
& $2044 \mathrm{~kg} / \mathrm{h}$ & Power generated in HPT & $2.6 \mathrm{MW}$ \\
& & Power generated in IPT & $0.8 \mathrm{MW}$ \\
Parameters of the air reactor & & Power consumed by pumps & $26.3 \mathrm{MW}$ \\
Operating temperature & $750{ }^{\circ} \mathrm{C}$ & Net power generated & $26.3 \%$ \\
Oxygen carrier circulation rate & $906 \mathrm{t} / \mathrm{h}$ & Net thermal efficiency & \\
\hline
\end{tabular}


Counterintuitively, the electricity-weighted net plant efficiency during dynamic operation is slightly higher than during steady-steady operation. This is because the BECCS plant runs for more hours per day and produces more energy than the CSP-CLAS system, and this inflates the calculated value.

The dynamic simulation of the process was carried out using the solar energy and electricity demand data of the month of July with different assumptions: In case $A$, the minimum load factor of the BECCS plant $\left(\mathrm{LF}_{\text {min }}\right)$ was set to zero, while in case $B$, case $C$ and case $D$, the value of $\mathrm{LF}_{\min }$ is $21 \%$. Ideally, the BECCS plant would shut off during the day when the CSPCLAS system produces sufficient energy to meet the electricity demand and operate only when the CSP-CLAS system does not produce (sufficient) electricity. However, solid fuel power plants do typically not offer this flexibility, amongst others, since this would cause excessive erosion of the bearings and deterioration of the reactor materials due to the large temperature changes. The value of $\mathrm{LF}_{\min }=21 \%$, which is used in case $B$, case $C$ and case $D$, is a more realistic assumption.

Furthermore, in case $A$ and case $B$, it is assumed that the active phase of the oxygen carriers, i.e. $\mathrm{Mn}_{2} \mathrm{O}_{3} / \mathrm{Mn}_{3} \mathrm{O}_{4}$, is unsupported. This is ideal from a thermodynamic standpoint, since the addition of a supporting material would result in a higher solid circulation rate. More material per unit of time would need to be heated in the reducer and subsequently cooled in the oxidiser. This effectively increases the transport of heat from the reducer to the oxidiser, which reduces the enthalpy that is available in the reducer for the endothermic $\mathrm{O}_{2}$ uncoupling, and thus in turn reduces the rate of $\mathrm{O}_{2}$ production in the CLAS process. During continuous redoxcycling unsupported $\mathrm{Mn}$ oxygen carriers would probably agglomerate. To prevent this, the $\mathrm{Mn}_{2} \mathrm{O}_{3}$ is supported on $30 \mathrm{wt} \% \mathrm{Al}_{2} \mathrm{O}_{3}$ and $60 \mathrm{wt} \% \mathrm{Al}_{2} \mathrm{O}_{3}$ in case $C$ and case $D$, respectively. The results of the four cases are shown in Fig. 7, below.

In Fig. 7(a), it can be seen that a process that operates with a $\mathrm{LF}_{\min }$ of zero and utilises unsupported $\mathrm{Mn}_{2} \mathrm{O}_{3}$ oxygen carriers is able to produce $0.10 \%$ of Spain's electricity while following the hourly variations of Spain's electricity demand. When setting the $\mathrm{LF}_{\min }$ to $0.21 \%$ (Fig. 7(b)), it is no longer possible to produce an electricity supply that is proportional to the demand: during mid-day the supply of power from the CLAS process and the BECCS plant result in excess electricity (5.3\% of the daily electricity production). Furthermore, only $0.09 \%$ of Spain's electricity demand can be supplied.

Supporting the active metal oxide on $30 \mathrm{wt} \% \mathrm{Al}_{2} \mathrm{O}_{3}$ (Fig. 7(c)) and $60 \mathrm{wt} \% \mathrm{Al}_{2} \mathrm{O}_{3}$ (Fig. $7(d)$ ) decreases the energy storage potential further, so that $0.08 \%$ and $0.05 \%$ of Spain's electricity demand are supplied, while producing around mid-day excess electricity that corresponds to $14.1 \%$ and $36.0 \%$ of the daily electricity production, respectively.

The reduction of the electricity production with increasing supporting material mass fraction, $\alpha_{\text {support }}$, is predominantly owing to the reduction of the $\mathrm{O}_{2}$ production rate. The additional material increases the heat transfer between the reducer and the oxidiser, which reduces the enthalpy available for air separation. Additionally, more supporting material (and thus a higher oxygen carrier circulation rate) requires more steam for the loop-seal fluidisation. This steam is withdrawn upstream of the low-pressure turbine and thus effectively reduces the power available for electricity generation. The reduction of $\mathrm{O}_{2}$ production and electricity production with an increase in support material mass fraction is illustrated in Fig. 8 (a and b), respectively.

The assumptions of case $C$ were deemed to be most realistic and were thus used to calculate the performance of the system over the course of a year. The maximum thermal power output of the BECCS plant for case $C$ in July (Fig. 7(c)) was 58.7 MW. Assuming that this 

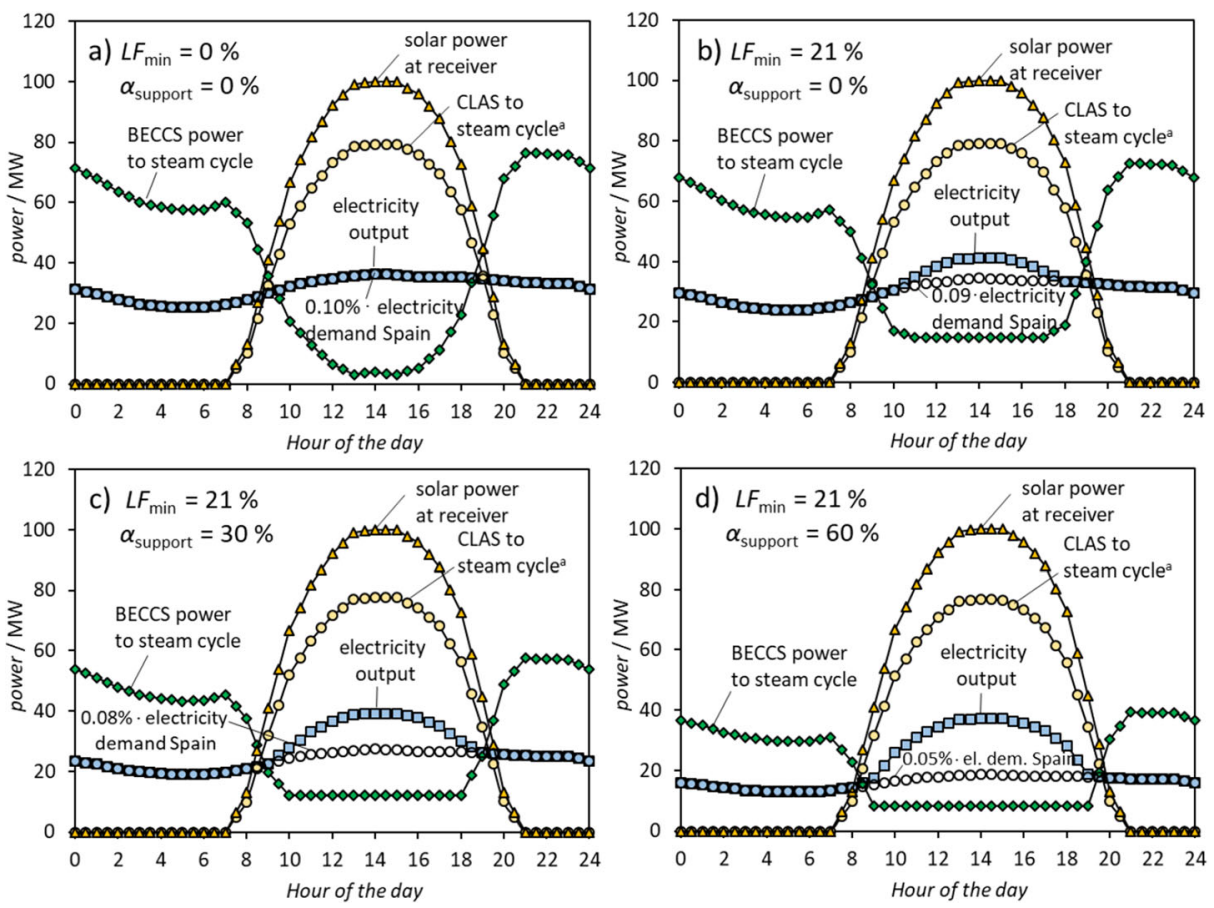

Fig. 7 Power inputs and outputs of the subsystems and electricity demand over the course of the day, based on solar beam irradiance data and electricity demand data for the month of July with varying assumptions: (a) no minimum load factor of the BECCS plant, $\mathrm{LF}_{\min }$, and (b, c, d) $\mathrm{LF}_{\min }=21 \% \sim 12.3 \mathrm{MW}$; (a, b) unsupported $\mathrm{Mn}_{2} \mathrm{O}_{3}$ oxygen carriers, (c) $\mathrm{Mn}_{2} \mathrm{O}_{3}$ supported on $30 \mathrm{wt} \% \mathrm{Al}_{2} \mathrm{O}_{3}$, and (d) $\mathrm{Mn}_{2} \mathrm{O}_{3}$ supported on $60 \mathrm{wt} \% \mathrm{Al}_{2} \mathrm{O}_{3}$

corresponds to a load factor of $100 \%$, the minimum load factor of $21 \%$ in this case corresponds to 12.3 MW. This power output was defined as the minimum power output of the BECCS plant for any given time and month of the year. Using the iteration procedure described in Section 2.5, the performance of the process was simulated for the different times of the year. The results are summarised in Table 4 below.
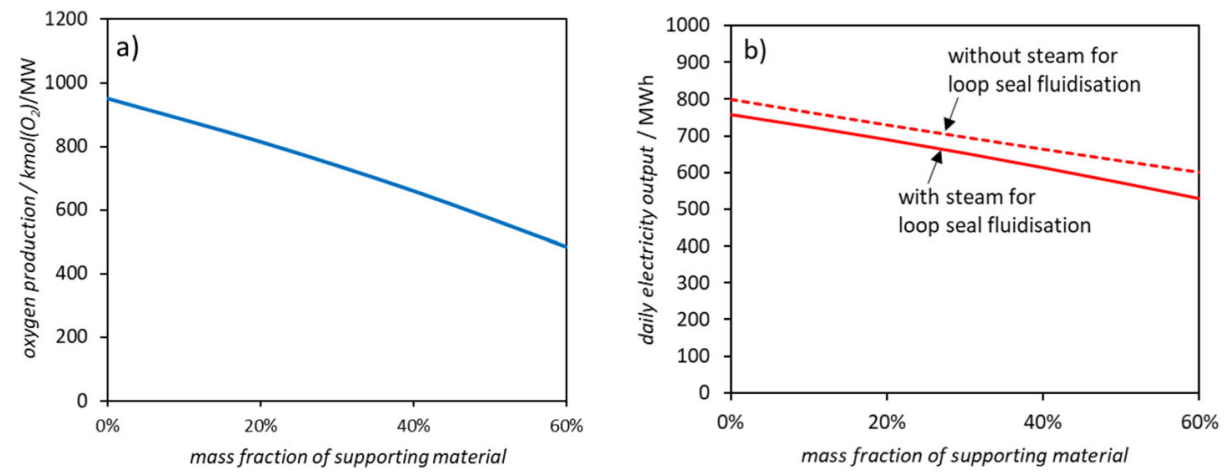

Fig. 8 Plots of (a) the oxygen production per MW heat added to the reducer and (b) the daily electricity output of the plant as a function of supporting material mass fraction. For (b), the solar power and electricity demand data for the month of July was taken, and a minimum load factor of the BECCS plant of $22 \%$ was assumed 


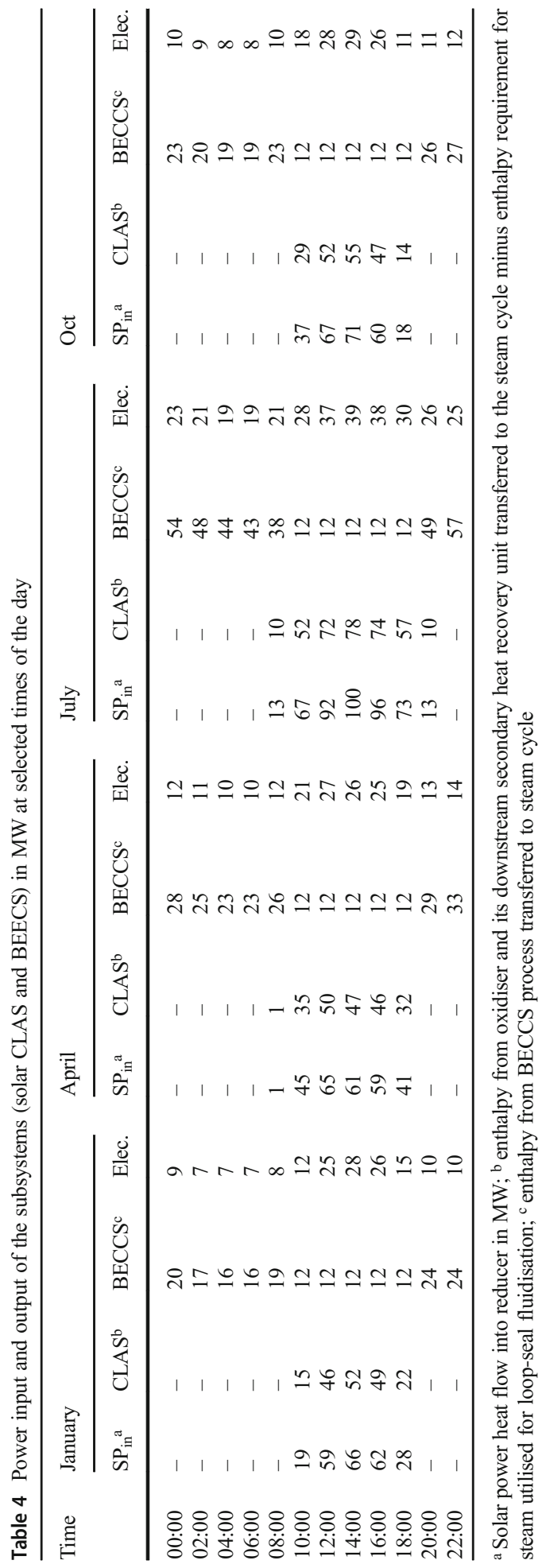


The results from Table 4 (together with further results of the simulation) are illustrated in Fig.9, below.

In Table 4 and Fig. 9, it can be seen that the daily electricity production of the system varies significantly with the seasons. While in January, 331 MWh (Fig.9(a)) is produced on an average day, the average daily electricity production for April, July and October is $397 \mathrm{MWh}$ (Fig. 9(b)), 621 MW (Fig. 9(c)) and 362 MW (Fig. 9(d)), respectively. The lower electricity production in the colder months is mainly caused by less solar radiation. On the one hand, this results in less power transferred from the CLAS process to the steam cycle, and on the other hand, a lower $\mathrm{O}_{2}$ production rate, which in turn results in less $\mathrm{O}_{2}+\mathrm{CO}_{2}$ being available for biomass combustion.

A reduced net plant efficiency and lower load factors of the BECCS are also caused by the lower solar radiation in the colder months. The monthly and annual average efficiencies (calculated for every hour using Eq. (7) and weighing the hourly values by the hourly electricity output) and the load factor of the BECCS process (calculated by dividing the actual daily power output by the maximum daily power output $(57.8 \mathrm{MW} \times 24 \mathrm{~h}))$ are reported in Table 5, below.

The size of the array of heliostats can be determined from Eq. (3), which relates the solar beam irradiance and the solar power produced. When solving this equation for the area of the solar reflectors, $A_{\mathrm{HS}}$, it results in a value of $237,200 \mathrm{~m}^{2}$. This area is about three times larger than the area of the reflectors which power the nominal 11-MW $\mathrm{el}$ Planta Solar 10 concentrated solar power plant $\left(74,880 \mathrm{~m}^{2}\right)$ in Seville (NREL 2018).
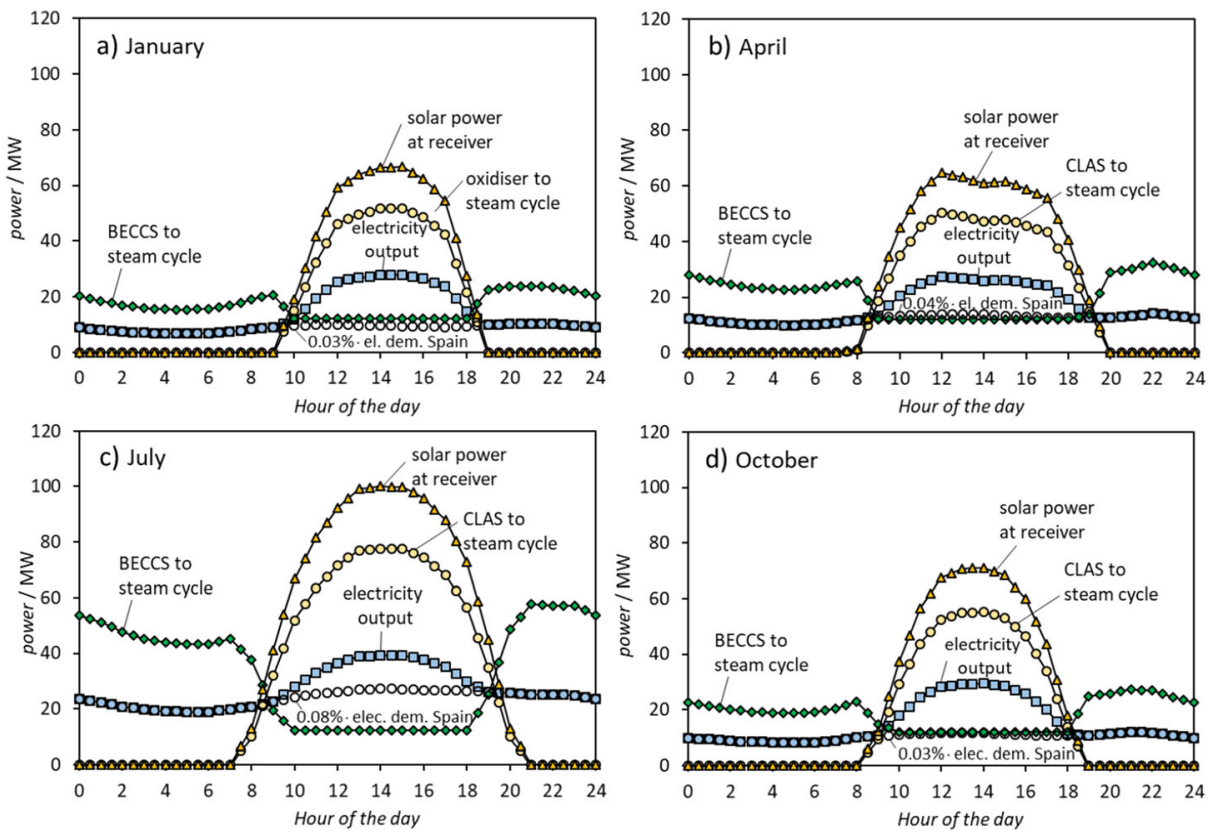

Fig. 9 Power inputs and outputs of the subsystems and electricity demand over the course of the day with the assumptions of 'case c' (c.f. Fig. 6(c)): a minimum load factor of the BECCS plant, $\mathrm{LF}_{\min }$, of 21\% 12.3 MW and oxygen carriers containing $\mathrm{Mn}_{2} \mathrm{O}_{3}$ and $30 \mathrm{wt} \% \mathrm{Al}_{2} \mathrm{O}_{3}$ for different months of the year: (a) January, (b) April, (c) July, and (d) October 
Table 5 Calculated thermal efficiencies and load factor of the CLAS + oxy-fuel

\begin{tabular}{|c|c|c|c|c|c|}
\hline $\begin{array}{l}\text { Case or } \\
\text { month }\end{array}$ & Assumptions & $\begin{array}{l}\text { Net plant } \\
\text { efficiency }\end{array}$ & $\begin{array}{l}\text { Load factor of } \\
\text { BECCS plant }{ }^{b}\end{array}$ & $\begin{array}{l}\text { Daily electricity } \\
\text { production }\end{array}$ & $\begin{array}{l}\text { Data } \\
\text { illustrated in }\end{array}$ \\
\hline \multicolumn{6}{|c|}{ Dynamic simulation of different cases using the solar radiation and electricity demand data for July } \\
\hline Case A & $\mathrm{LF}_{\min }=0, \alpha_{\text {support }}=0 \%$ & $27.6 \%$ & $72 \%$ & $758.0 \mathrm{MWh}$ & Fig. 7(a) \\
\hline Case B & $\mathrm{LF}_{\min }=21 \%, \alpha_{\text {support }}=0 \%$ & $27.4 \%$ & $72 \%$ & $758.0 \mathrm{MWh}$ & Fig. 7(b) \\
\hline Case C & $\mathrm{LF}_{\min }=21 \%, \alpha_{\text {support }}=30 \%$ & $26.1 \%$ & $56 \%$ & $651.3 \mathrm{MWh}$ & Fig. $7(\mathrm{c})$ \\
\hline Case D & $\mathrm{LF}_{\min }=21 \%, \alpha_{\text {support }}=60 \%$ & $24.1 \%$ & $37 \%$ & $529.6 \mathrm{MWh}$ & Fig. 7(d) \\
\hline \multicolumn{6}{|c|}{ Dynamic simulation of case $\mathrm{C}\left(\mathrm{LF}_{\min }=21 \%, \alpha_{\text {support }}=30 \%\right)$ for various months } \\
\hline January & $\mathrm{LF}_{\min }=21 \%, \alpha_{\text {support }}=30 \%$ & $26.0 \%$ & $28 \%$ & $331.4 \mathrm{MWh}$ & Fig. 9(a) \\
\hline April & $\mathrm{LF}_{\min }=21 \%, \alpha_{\text {support }}=30 \%$ & $25.3 \%$ & $34 \%$ & $396.8 \mathrm{MWh}$ & Fig. 9(b) \\
\hline July & $\mathrm{LF}_{\min }=21 \%, \alpha_{\text {support }}=30 \%$ & $26.1 \%$ & $56 \%$ & $651.3 \mathrm{MWh}$ & Fig. 9(c) \\
\hline October & $\mathrm{LF}_{\min }=21 \%, \alpha_{\text {support }}=30 \%$ & $26.0 \%$ & $31 \%$ & $362.4 \mathrm{MWh}$ & Fig. 9(d) \\
\hline Year (average) & - & $26.6 \%$ & $41 \%$ & 469.0 MWh & - \\
\hline
\end{tabular}

a The net plant efficiency was calculated using Eq. (4) for every hour of the day, and the reported value is the electricity output-weighted average of the hourly efficiencies; ${ }^{b}$ the average load factor of the BECCS plant was calculated by dividing the actual daily thermal output of the BECCS plant by the theoretical maximum thermal output $(58.7 \mathrm{MW} \times 24 \mathrm{~h})$

\subsection{The storage requirements for $\mathrm{O}_{2}+\mathrm{CO}_{2}$ and $\mathrm{CO}_{2}$}

The results from the dynamic simulation for the year allow to calculate the gas storage requirements. The storage requirements for $\mathrm{O}_{2}+\mathrm{CO}_{2}$, which is used for oxy-fuel combustion, are calculated in this section. Simultaneously, a similar amount of recycled $\mathrm{CO}_{2}$ has to be stored for utilisation in the CLAS process (not calculated here). The highest storage requirement for $\mathrm{O}_{2}+\mathrm{CO}_{2}$ is in the summer (i.e. July), when up to $779 \mathrm{t}$ of the gas has to be stored for later use (working gas). Assuming additional $500 \mathrm{t}$ of $\mathrm{O}_{2}+\mathrm{CO}_{2}$ as a buffer gas, the storage has to accommodate 1279 t of $\mathrm{O}_{2}+\mathrm{CO}_{2}$. In January, the $\mathrm{O}_{2}+\mathrm{CO}_{2}$ storage requirement is the lowest: only $876 \mathrm{t}$ ( $500 \mathrm{t}$ buffer gas $+376 \mathrm{t}$ working gas) has to be stored, as a lower solar power input results in a lower $\mathrm{O}_{2}$ production. The hourly amount of storage for the different seasons is illustrated in Fig. 10, below.

The volume required for storage in July corresponds to $215,066 \mathrm{~m}^{3}$, which is comprised of $130,990 \mathrm{~m}^{3}$ for working gas and $84,076 \mathrm{~m}^{3}$ for buffer gas. This calculation assumes a density of the $\mathrm{O}_{2}+\mathrm{CO}_{2}$ mixture $\left(27.0\right.$ vol\% $\left.\mathrm{O}_{2}+\mathrm{CO}_{2}\right)$ of $5.947 \mathrm{~kg} / \mathrm{m}^{3}$ at $20{ }^{\circ} \mathrm{C}$ and 6 bar. In comparison, the average working gas capacity of the salt caverns in Europe that were in operation as of end 2016 is $389,362 \mathrm{~m}^{3}$, which is almost two times the volume required for the process of this study (Cornot-Gandolphe 2017). We assumed operation of the cavern in the pressure range between 2 and 6 bar-higher pressures would increase inefficiencies during compression and de-compression. However, caverns with a smaller volume could be used with a higher operating pressure to meet the gas storage requirements, or alternatively (additional) surface gas storage could be erected.

\subsection{Factors effecting the efficiency of the process}

The net plant efficiency is significantly impacted by the thermal efficiency of the steam cycle. The latter is $43.7 \%$. During sole operation of the CSP-CLAS plant (i.e. at mid-day), the thermal efficiency of the system is $17.8 \%$ (assuming a solar field efficiency, $\eta_{H S+R}$, of $49.0 \%)$. This is slightly lower than a CSP plant with the same solar field (49.0\%) and steam cycle efficiency $(43.7 \%)$ in which the incoming solar power at the receiver is directly 


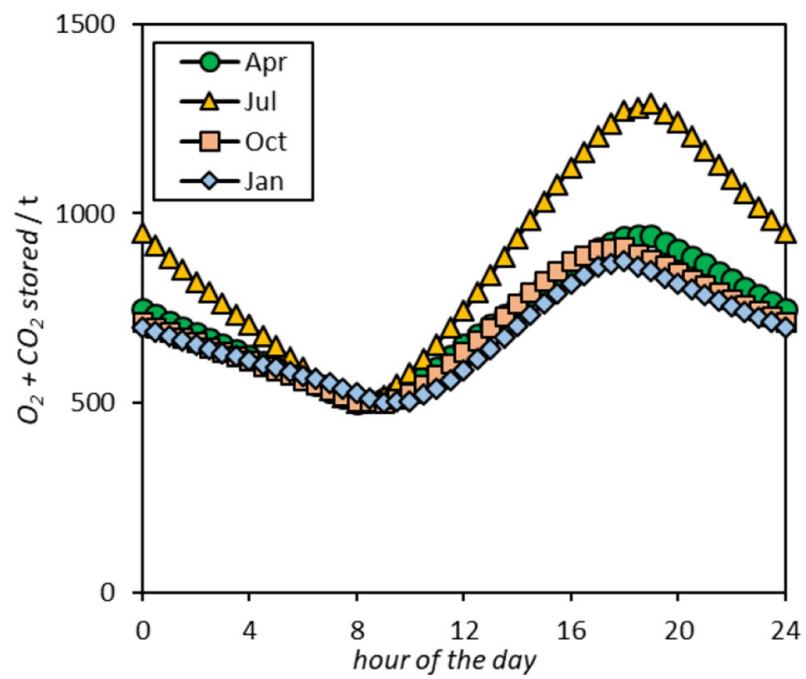

Fig. 10 The change of mass of $\mathrm{O}_{2}+\mathrm{CO}_{2}\left(27\right.$ vol\% $\left.\mathrm{O}_{2}+\mathrm{CO}_{2}\right)$ stored over the course of the day for different months

transferred to the steam cycle $(21.4 \%)$ (Zhang et al. 2013). A minor part of this energy penalty can be attributed to some heat being lost (1.1\%), e.g. when discharging the $\mathrm{O}_{2-}$ deficient air at $70{ }^{\circ} \mathrm{C}$ to the atmosphere or when storing the $\mathrm{O}_{2}+\mathrm{CO}_{2}$ with $80{ }^{\circ} \mathrm{C}$ in the underground. Though, the major part of the energy penalty comes from the steam requirements for loop-seal fluidisation, which is withdrawn from the inlet of the low-pressure turbine. The reduction in electricity production varies depending on the oxygen carriers' support loading in the range between $12.2 \%$ (unsupported) and $15.1 \%$ (60 wt $\% \mathrm{Al}_{2} \mathrm{O}_{3}$ ). It is worth mentioning that in the CLAS process, the steam requirements for loop-seal fluidisation are typically larger than during the CLC process, owing to a lower $\mathrm{O}_{2}$ storage capacity of the active phases. For example, in the case of Mn-based oxygen carriers, the transition between $\mathrm{Mn}_{2} \mathrm{O}_{3}$ and $\mathrm{MnO}$ during in a fuelled CLC process corresponds to an $\mathrm{O}_{2}$ storage capacity of $10.1 \mathrm{wt} \%$, while the transition between $\mathrm{Mn}_{2} \mathrm{O}_{3}$ and $\mathrm{Mn}_{3} \mathrm{O}_{4}$ results in an $\mathrm{O}_{2}$ storage capacity of only $3.4 \mathrm{wt} \%$. To provide the same amount of $\mathrm{O}_{2}$ per unit of time, the oxygen carrier circulation rate has to be three times higher in the CLAS process than in the CLC process assuming full conversion. When assuming the steam requirements scale linearly with the oxygen carrier circulation rate, three times more steam is required for the fluidisation of the loop-seals. The thermal efficiency of the process during sole operation of the BECCS plant is $37.0 \%$; this efficiency could be increased by operation of the oxy-fuel combustor at elevated pressure and expansion of the combustion products using a gas-turbine for additional electricity generation (i.e. a combined cycle approach). However, since the remaining parts of the process were already relatively complex, it was decided not to increase the complexity further.

\subsection{The $\mathrm{CO}_{2}$ capture rate of the system}

Using the results of the dynamic simulation, the amount of $\mathrm{CO}_{2}$ captured was calculated. A capture efficiency of $98 \%$ was assumed. The hourly results for the different months are shown in Fig. 11, below. 


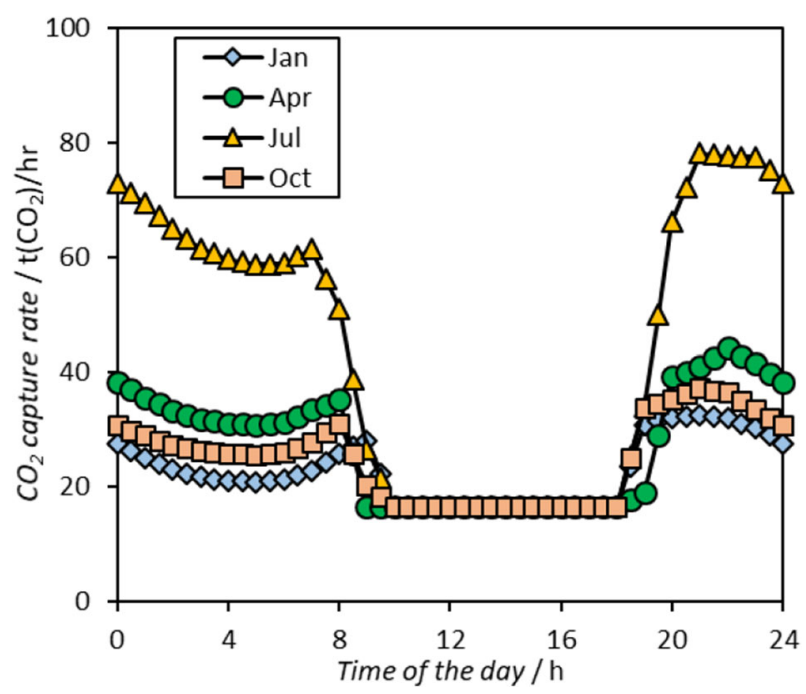

Fig. 11 The hourly $\mathrm{CO}_{2}$ capture rate of the system simulated for different months. The oxygen carriers were $\mathrm{Mn}_{2} \mathrm{O}_{3}$ supported on $30 \mathrm{wt} \% \mathrm{Al}_{2} \mathrm{O}_{3}$ and a minimum load factor of $21 \%$ for the BECCS plant was assumed

Figure 11 shows that the daily amounts of $\mathrm{CO}_{2}$ captured vary seasonally between January (543.1 t/day) and July (1067.5 t/day). Over the course of a year, the process is able to capture 260,517 tonnes of $\mathrm{CO}_{2}$.

\section{Conclusions}

We report the results of a dynamic simulation of a system that combines a CSP-CLAS process with an oxy-fuel combustion process for $\mathrm{CO}_{2}$ capture. The fuel for the combustion is olive tree pruning, which is a locally produced agricultural residue. The CSP process was sized for a maximum concentrated solar power heat flow of $100 \mathrm{MW}$ into the reducer (i.e. reached at midday in the summer months). It was calculated that the system is able to utilise $2.43 \%$ of Andalusia's olive tree pruning production, thereby capturing $260.5 \mathrm{k}$-tonnes of $\mathrm{CO}_{2}$ per year and producing an average power output of $18 \mathrm{MW}$. Owing to the synergies of the two subprocesses, solar energy is effectively stored as $\mathrm{O}_{2}+\mathrm{CO}_{2}$ during the day, which allows for operation of the BECCS process for the production of negative $\mathrm{CO}_{2}$ emissions predominantly at night. When using the solar beam irradiance data for July and using ideal assumptions (unsupported $\mathrm{Mn}_{2} \mathrm{O}_{3}$ oxygen carriers and no minimum load factor for the BECCS plant), it was possible to achieve an electricity output that is proportional to Spain's electricity demand, thereby constantly providing $0.10 \%$ of Spain's electricity. However, when supporting the active metal oxide and setting a minimum load factor of the BECCS plant of $21 \%$, the $\mathrm{O}_{2}$ production and thus the solar energy storage potential decreased significantly. This resulted in the production of excess energy at mid-day. Furthermore, it was found that when considering steam requirements for loop-seal fluidisation (the steam was taken from the inlet of the lowpressure turbine), the electricity production from the enthalpy transferred from the CLAS process to the steam cycle decreased by $12.2-15.1 \%$ for oxygen carrier support loadings of 0 $60 \mathrm{wt} \%$. This study also showed that dynamic simulations over the course of a year are essential to predict the performance of such synergetic processes realistically: In colder 
months, with less available solar power, the process provides a significantly lower electricity output. For example, the average daily electricity production in January is $331.4 \mathrm{MWh}$, while the value for July is 631.2 MWh. Furthermore, relatively large gas storages are required, which either decrease the number of possible locations (e.g. has to be situated near a salt cavern that is suitable for gas storage) or expensive surface gas tanks have to be constructed.

Despite several drawbacks and the relatively high complexity of this process, it might still be a promising negative emissions technology (NET). It shall be remembered that the main objective of the process of this study is not the production of inexpensive electricity, but an economically viable net removal of $\mathrm{CO}_{2}$ from the atmosphere. The cost of $\mathrm{CO}_{2}$ capture (subsidised by the selling of electricity) will likely be lower than that of first-generation direct air capture systems, and the economics of the process will further improve when considering a (future) price on $\mathrm{CO}_{2}$ emissions (e.g. carbon tax). Furthermore, the process utilises a locally produced agricultural residue, which is favourable as it eliminates the risk that the production of the fuel (biomass) is competing with the production of food, and excessive $\mathrm{CO}_{2}$ emissions for the transport of the fuel are unlikely.

To ultimately assess the performance and economics of this process, further in-depth studies are needed that focus on specific design aspects (e.g. improvement of loop-seals), operational aspects (e.g. effect of short-term fluctuations in solar radiation on the reactor temperature and thus $\mathrm{O}_{2}$ production rate, the effect of the support material on the oxygen carrier lifetime), economic aspects (e.g. a detailed calculation of the capital and operating costs of the process) and environmental aspects (e.g. the compilation of a life cycle assessment).

\subsection{Strategy recommendations}

Though the process studied in this work is relatively complex (e.g. when considering the number of reactors) and its thermal efficiency is inferior to state-of-the-art fossil fuel power plants, it is still promising. This is because it utilises a waste product (agricultural residues), which is inexpensive and abundant, thereby enabling the net removal of $\mathrm{CO}_{2}$ from the atmosphere. It was calculated that the system in this study sequesters the carbon from $2.43 \%$ of Andalusia's annual olive grove (Olea europaea) production. Thus, 41 of such systems (or other BECCS systems with a similar fuel burn rate) could utilise Andalusia's entire olive grove production, thereby capturing 10.72 million tons of $\mathrm{CO}_{2}$ annually. Figure 2 shows that other types of biomass are readily available in Andalusia for use in BECCS processes. Other parts of the world also produce annually high quantities of agricultural residues (e.g. shell, straw and stalk of agricultural plants), such as root crops (e.g. Dioscorea alata) in Africa (55.0 million tonnes); wheat (Triticum) and rice (Oryza sativa) in Asia (835.6 million tonnes); sugar cane (Saccharum officinarum), maize (Zea mays) and legumes (Fabaceae) in Latin America (157.6 million tonnes); and wheat (Triticum) in Europe, the former Soviet Union and Oceania (291.3 million tonnes) according to Hall et al. (Hall and Overend 1987). When considering all types of agricultural crops, the total mass of agricultural residues annually produced worldwide was estimated to be 3135 million tonnes (Hall and Overend 1987). A more recent calculation by Lal (2005) — though not divided by region - was based on the data of the Food and Agriculture Organization of the United Nations (FAO 2002). It estimated the annual global agricultural residue production to be 3758 million tonnes. Given the large quantity of residues and waste being produced worldwide, many of such niche processes with inherent $\mathrm{CO}_{2}$ capture, tailored to location and fuel's characteristics, could play a crucial role in the reduction of global $\mathrm{CO}_{2}$ emissions. We recommend that new processes that 
utilise waste products and residues for $\mathrm{CO}_{2}$-neutral or $\mathrm{CO}_{2}$-negative electricity generation should be screened for economic viability under consideration of a (future) carbon tax, integration potential with a likely electricity grid system, and using the local conditions and real data. As done in this work, the combination of energy systems using different types of energy carriers (here solar and biomass) should be tested in combination to identify synergies. Instead of curtailing excess solar and wind power, it should be used (when reasonable) for power storage, conversion and production.

Funding information This work was funded by the Engineering and Physical Sciences Research Council (EPSRC) as part of the RCUK Energy Programme under EP/P026214/1. The authors thank the Department of Chemical Engineering at Imperial College London and the Public Authority of Applied Education and Training in Kuwait for the funding of $\mathrm{PhD}$ scholarships.

Open Access This article is distributed under the terms of the Creative Commons Attribution 4.0 International License (http://creativecommons.org/licenses/by/4.0/), which permits unrestricted use, distribution, and reproduction in any medium, provided you give appropriate credit to the original author(s) and the source, provide a link to the Creative Commons license, and indicate if changes were made.

\section{References}

AspenTech (2013) ASPEN Plus - Getting Started Modeling Processes with Solids. Version Number: V8.4. Aspen Technology, Inc., Burlington

Barlev D, Vidu R, Stroeve P (2011) Innovation in concentrated solar power. Sol Energy Mater Sol Cells 95(10): 2703-2725

Blair N, DiOrio N, Freeman J, Gilman P, Janzou S, Neises T and Wagner M (2018) System Advisor Model (SAM). www.nrel.gov/docs/fy18osti/70414.pdf. Accessed 31 March 2019

Cho P, Mattisson T, Lyngfelt A (2004) Comparison of iron-, nickel-, copper- and manganese-based oxygen carriers for chemical-looping combustion. Fuel 83(9):1215-1225

Cornot-Gandolphe S (2017) Underground Gas Storage in the World - 2017 Status. Cedigaz Insights No. 22

ENTSOE (2018) The European Network of Transmission System Operators for Electricity: hourly load values of a specific country: Spain. www.entsoe.eu. Accessed 28 December 2017

FAO (2002) FAO Production Yearbook 2001. Statistics Div., Food and Agricultural Organization of the United Nations (FAO), Rome

García-Maraver A, Zamorano M, Ramos-Ridao A, Díaz LF (2012) Analysis of olive grove residual biomass potential for electric and thermal energy generation in Andalusia (Spain). Renew Sust Energ Rev 16(1):745751

Hall DO, Overend RP (1987) Biomass: Regenerable Energy (World Energy Options). Wiley-Blackwell

IPCC (2005) IPCC special report on carbon dioxide capture and storage. Cambridge University Press, Cambridge

Karlsson H, Byström L (2011) Global status of BECCS projects 2010. Australia, Global CCS Institute, Canberra Lal R (2005) World crop residues production and implications of its use as a biofuel. Environ Int 31(4):575-584

Li Z-s, Zhang T, N-s C (2008) Experimental study of $\mathrm{O}_{2}-\mathrm{CO}_{2}$ production for the oxyfuel combustion using a CO-based oxygen carrier. Ind Eng Chem Res 47(19):7147-7153

Lyngfelt A, Leckner B, Mattisson T (2001) A fluidized-bed combustion process with inherent $\mathrm{CO}_{2}$ separation; application of chemical-looping combustion. Chem Eng Sci 56(10):3101-3113

Marx K, Bertsch O, Pröll T, Hofbauer H (2013) Next scale chemical looping combustion: process integration and part load investigations for a 10MW demonstration unit. Energy Procedia 37:635-644

Moghtaderi B (2010) Application of chemical looping concept for air separation at high temperatures. Energy Fuel 24(1):190-198

NREL (2018) Concentrating solar power projects: Planta Solar 10. https:/www.nrel.gov/csp/solarpaces/project_ detail.cfm/projectID=38. Accessed 28 December 2017

Porrazzo R, White G, Ocone R (2016) Techno-economic investigation of a chemical looping combustion based power plant. Faraday Discuss Chem Soc 192:437-457

Riaza J, Gil MV, Álvarez L, Pevida C, Pis JJ, Rubiera F (2012) Oxy-fuel combustion of coal and biomass blends. Energy 41(1):429-435 
Shah K, Moghtaderi B, Wall T (2012) Selection of suitable oxygen carriers for chemical looping air separation: a thermodynamic approach. Energy Fuel 26(4):2038-2045

Shah K, Moghtaderi B, Wall T (2013) Effect of flue gas impurities on the performance of a chemical looping based air separation process for oxy-fuel combustion. Fuel 103:932-942

Song H, Shah K, Doroodchi E, Wall T, Moghtaderi B (2014) Analysis on chemical reaction kinetics of CuO/ $\mathrm{SiO}_{2}$ oxygen carriers for chemical looping air separation. Energy Fuel 28(1):173-182

Tagliaferri C, Görke R, Scott S, Dennis J, Lettieri P (2018) Life cycle assessment of optimised chemical looping air separation systems for electricity production. Chem Eng Res Des 131:686-698

Vamvuka D, Tsamourgeli V, Galetakis M (2014) Study on catalytic combustion of biomass mixtures with poor coals. Combust Sci Technol 186(1):68-82

Zerobin F, Bertsch O, Penthor S, Pröll T (2016) Concept study for competitive power generation from chemical looping combustion of natural gas. Energy Technol 4(10):1299-1304

Zhang HL, Baeyens J, Degrève J, Cacères G (2013) Concentrated solar power plants: review and design methodology. Renew Sust Energ Rev 22:466-481

Zhou C, Shah K, Moghtaderi B (2015) Techno-economic assessment of integrated chemical looping air separation for oxy-fuel combustion: an Australian case study. Energy Fuel 29(4):2074-2088

Publisher's note Springer Nature remains neutral with regard to jurisdictional claims in published maps and institutional affiliations. 